\title{
Implikasi Hukum Penggunaan Surat Kuasa Membebankan Hak Tanggungan Sebagai Jaminan Dalam Perjanjian Kredit Pemilikan Rumah
}

\author{
Siti Malikhatun Badriyah, R. Suharto, H.Kashadi \\ Muhammad Shafiyuddin Wafi \\ Fakultas Hukum Universitas Diponegoro \\ JL. Prof. Sudharto No. 1 Semarang, Jawa Tengah, 50275 \\ sitimalikhatun@live.undip.ac.id
}

\begin{abstract}
In the agreement a strong guarantee is needed to provide legal protection for the parties. One of them is Encumbrance Right. Encumbrance Right occur after registration of Underwriting Rights at the Land Office. But in practice, often the Encumbrance Right only reaches the making of Power Of Attorney To Establish Encumbrance Right (SKMHT). This study aims to find evidence and analyze the use of SKMHT in the Housing Ownership Credit (KPR) agreement and its legal consequences if the debtor defaults. The research method used is qualitative with a socio legal approach. The results of the study indicate that in the KPR agreement many liability rights are imposed by using SKMHT without being followed by the making of the Deed of Giving Encumbrance Rights and the Registration of Encumbrance Rights. As a result, Encumbrance Rights do not occur, so that if the debtor defaults on the creditor does not have the right of execution as the holder of the Encumbrance Rights as determined in the Encumbrance Rights Act.
\end{abstract}

Keywords: encumbrance rights, credit, default.

\begin{abstract}
ABSTRAK
Dalam perjanjian dibutuhkan jaminan yang kuat untuk memberikan perlindungan hukum bagi para pihak. Salah satunya adalah Hak Tanggungan. Hak Tanggungan terjadi setelah pendaftaran Hak Tanggungan di Kantor Pertanahan. Namun dalam praktik seringkali Hak Tanggungan hanya sampai pada pembuatan Surat Kuasa Membebankan Hak Tanggungan (SKMHT). Penelitian ini bertujuan untuk mencari bukti-bukti dan menganalisis penggunaan SKMHT dalam perjanjian Kredit Pemilikan Rumah (KPR) serta akibat hukumnya jika debitor wanprestasi. Metode penelitian yang digunakan adalah kualitatif dengan pendekatan socio legal. Hasil penelitian menunjukkan bahwa dalam perjanjian KPR banyak dilakukan pembebanan Hak Tanggungan dengan menggunakan SKMHT tanpa diikuti dengan pembuatan Akta Pemberian Hak Tanggungan dan Pendaftaran Hak Tanggungan. Akibatnya Hak Tanggungan tidak terjadi, sehingga jika debitor wanprestasi kreditor tidak memiliki hak eksekusi sebagai Penerima Hak Tanggungan sebagaimana ditentukan dalam Undang-undang Hak Tanggungan.
\end{abstract}

Kata Kunci: hak tanggungan, kredit, surat kuasa, hak tanggungan, wanprestasi. 


\section{PENDAHULUAN}

Pesatnya perkembangan masyarakat terutama dalam bidang perekonomian mengakibatkan perkembangan kebutuhan masyarakat juga makin berkembang dengan pesat. Salah satunya adalah kebutuhan papan atau tempat tinggal. Aneka metode digunakan oleh pelaku usaha untuk mengembangkan usahanya termasuk dalam penyediaan perumahan untuk konsumen. Penggunaan cara pembayaran angsuran menjadi daya tarik tersendiri bagi konsumen. Oleh karena itu berbagai lembaga pembiayaan menyediakan fasilitas Kredit Pemilikan Rumah (KPR).

Sebagai salah satu perjanjian, KPR harus diberikan dengan jaminan kepastian hukum bagi pihak-pihak yang berkepentingan. Hal ini sesuai dengan asas dalam pelaksanaan dan penegakan hukum harus memperhatikan tiga nilai dasar sebagaimana dikemukakan oleh Sudikno Mertokusumo ${ }^{1}$, Siti Malikhatun Badriyah ${ }^{2}$ dengan mengacu pada pendapat Gustav Radbruch yaitu kepastian hukum (rechtssicherheit), kemanfaatan (zweckmassigkeit) dan keadilan (gerechtigkeit). Salah satunya adalah dengan membuat perjanjian kredit pemilikan rumah yang yang menimbulkan hak dan kewajiban bagi pihak-pihak tersebut. Perjanjian KPR merupakan perjanjian pokok yang diikuti dengan perjanjian jaminan sebagai perjanjian tambahan. Keduanya dibuat secara terpisah, namun kedudukan perjanjian jaminan sangat tergantung dari perjanjian pokoknya. Pemberian jaminan dilakukan untuk memberikan perlindungan hukum kepada pihak kreditor. $^{3}$

Dalam praktik, setiap pemberian kredit oleh bank selalu disertai dengan penyerahan jaminan oleh debitor, yang pelaksanaan pengikatan jaminan tersebut dilakukan pada saat penandatangan perjanjian kredit. Salah satu jaminan yang sering digunakan adalah Hak Tanggungan. ${ }^{4}$

Perjanjian kredit di Indonesia belum ada aturan khusus, oleh karena itu sebagai dasar bagi pelaksanaan perjanjian kredit adalah ketentuan di dalam KUH Perdata. Pasal 1754

\footnotetext{
${ }^{1}$ Sudikno Mertokusumo dan Mr. A. Pitlo, Bab-Bab Tentang Penemuan Hukum (Chapters on Rechsvinding), 2nd ed., Jakarta, in collaboration with the Ministry of Education and Culture Law Consortium and The Asia Foundation, 2013.

${ }^{2}$ Siti Malikhatun Badriyah, Penemuan Hukum Dalam Konteks Pencarian Keadilan, Semarang, Badan Penerbit Universitas Diponegoro, 2010.

${ }^{3}$ Dimas Nur Arif Putra Suwandi, Perlindungan Hukum Bagi Bank Pemegang Hak Tanggungan Peringkat Kedua Dalam Eksekusi Objek Hak Tanggungan, Media Iuris 1, No. 3 tahun 2019, hal. 420.

${ }^{4}$ Siti Malikhatun Badriyah, Problematika Pembebanan Hak Tanggungan, Masalah - Masalah Hukum 45, No. 3 Tahun 2016, hal. 173-80.
} 
sampai dengan Pasal 1769 KUHPerdata menjadi dasar dari perjanjian kredit, yang di dalamnya diatur ketentuan-ketentuan mengenai perjanjian pinjam meminjam uang ataupun barang-barang yang habis karena pemakaian dan dipersyaratkan bahwa pihak yang berhutang atau debitor akan mengembalikan pinjamannya pada kreditor dalam jumlah yang sama dari macam dan keadaan yang sama pula. Selanjutnya disebutkan juga bahwa perjanjian tersebut dapat disertai dengan bunga yang telah diperjanjikan sebelumnya antara pihak-pihak, sehingga perjanjian kredit dapat dimasukkan dalam perjanjian pinjammeminjam dengan memperjanjikan bunga.

Selain perjanjian kredit sebagai perjanjian pokok, maka diperlukan juga adanya perjanjian penjaminan baik berupa benda bergerak maupun benda tidak bergerak. Untuk itu diperlukan lembaga hak jaminan yang kuat dan mampu memberi kepastian hukum bagi pemberi dan penerima kredit serta pihak lain yang terlibat melalui lembaga ini, ${ }^{5}$ salah satunya adalah Hak Tanggungan.

Kelahiran Undang-Undang No. 4 Tahun 1996 tentang Hak Tanggungan Atas Tanah Beserta Benda-Benda Yang Berkaitan Dengan Tanah (UUHT) merupakan suatu jawaban atas amanah yang ditetapkan dalam Undang-Undang Dasar 1945 dan Undang-Undang Pokok Agraria yaitu adanya unifikasi dalam lembaga jaminan di Indonesia, di samping untuk memenuhi kebutuhan akan modal yang semakin besar untuk keperluan pembangunan. Sejak keluarnya UUHT Hypotheek dan Credietverband tidak diberlakukan lagi. ${ }^{6}$

Keberadaan Undang-Undang Hak Tanggungan bagi sistem Hukum Perdata khususnya Hukum Jaminan yaitu dalam rangka memberikan kepastian hukum yang seimbang dalam bidang pengikatan jaminan atas benda-benda yang berkaitan dengan tanah sebagai jaminan bagi kreditor, debitor maupun pemberi Hak Tanggungan dan pihak ketiga yang terkait.

Terjadinya Hak Tanggungan ini melalui dua tahap yaitu tahap pemberian hak tanggungan dan tahap pendaftaran hak tanggungan. Dalam memberikan Hak Tanggungan, pemberi Hak Tanggungan wajib hadir di hadapan PPAT. Jika karena sesuatu sebab tidak dapat hadir sendiri, maka dapat menunjuk pihak lain sebagai kuasanya, dengan Surat Kuasa

\footnotetext{
${ }_{5}^{5}$ Denico Doly, Aspek Hukum Hak Tanggungan Dalam Pelaksanaan Roya, Negara Hukum, Membangun Hukum Untuk Keadilan Dan Kesejahteraan, No. 1 Tahun 2011, hal. 103-28.

${ }^{6}$ St. Nurjannah, Hak Eksistensi Tanggungan Sebagai Lembaga Jaminan Hak Atas Tanah (Tinjauan Filosofis), Jurisprudentie Jurusan Ilmu Hukum Fakultas Syariah Dan Hukum, No. 1 Tahun 2019, hal. 195.
} 
Vol 2, No. (2019): Law, Development \& Justice Review, Mei 2019. e-ISSN: 2655-1942

Membebankan Hak Tanggungan, disingkat SKMHT. ${ }^{7}$ Pembuatan SKMHT harus dengan akta otentik. $^{8}$

SKMHT terhadap hak atas tanah yang sudah terdaftar wajib diikuti dengan pembuatan Akta Pemberian Hak Tanggungan (APHT) dalam waktu 1 (satu) bulan setelah diberikan. SKMHT untuk hak atas tanah yang belum terdaftar wajib diikuti dengan pembuatan APHT selambat-lambatnya 3 (tiga) bulan sesudah diberikan. Jangka waktu tersebut tidak berlaku untuk kredit tertentu berdasarkan perundang-undangan yang berlaku. Untuk kredit tertentu seperti Kredit Pemilikan Rumah jangka waktu SKMHT ditentukan jangka waktunya sampai habis masa perjanjian kredit.

Dalam praktik banyak pembuatan SKMHT tidak segera diikuti dengan pembuatan APHT, sedangkan terjadinya hak tanggungan adalah pada saat didaftarkan di Kantor Pertanahan. Untuk adanya pendaftaran hak tanggungan sudah tentu terlebih dahulu ada pembuatan APHT di hadapan PPAT. Seringkali dalam masa sebelum dibuat APHT debitor wanprestasi. Hal ini menimbulkan permasalahan tersendiri terutama sangat berisiko bagi kreditor. Oleh karena itu penelitian tentang penelitian ini sangat urgen untuk dilaksanakan.

Berdasarkan uraian di atas, maka dalam penelitian ini diangkat beberapa permasalahan sebagai berikut:

1. Bagaimana penggunaan Surat Kuasa Membebankan Hak Tanggungan sebagai jaminan dalam Kredit Pemilikan Rumah?

2. Bagaimana jika dalam masa pembebanan Hak Tanggungan dilaksanakan dengan menggunakan SKMHT ternyata debitor wanprestasi?

\section{METODE PENELITIAN}

Penelitian ini mengunakan metode yuridis empiris dengan melakukan penelitian kepustakaan untuk memperoleh data sekunder dan penelitian lapangan untuk memperoleh data primer untuk mendapatkan bukti-bukti dan menganalisis tentang penggunaan surat kuasa membebankan Hak Tanggungan dalam perjanjian kredit pemilikan rumah. Spesifikasi penelitian ini adalah deskriptip analitis. Data sekunder diperoleh dengan teknik studi

\footnotetext{
${ }_{7}^{7}$ Ayang Fristia Maulana, Surat Kuasa Membebankan Hak Tanggungan Atas Tanah Negara, Jurnal 4, No. 2 Tahun 2017, ISSN: 1693-4458 E-ISSN: 2598-5906, hal. 192-204.

${ }^{8}$ Made Oka Cahyadi, Surat Kuasa Membebankan Hak Tanggungan Dan Pengaruhnya Terhadap Pemenuhan Asas Publisitas Dalam Proses Pemberian Yuridis Hak Tanggungan, Jurnal Legislasi Indonesia Volume 14 No. 4 Tahun 2017, hal. 439-46.
} 
Vol 2, No. (2019): Law, Development \& Justice Review, Mei 2019. e-ISSN: 2655-1942

pustaka, yang meliputi bahan hukum primer maupun bahan hukum sekunder. Data primer lapangan diperoleh dengan teknik wawancara dengan informan penelitian yang meliputi Kantor Badan Pertanahan Nasional Kota Semarang, PPAT di Kota Semarang, Konsumen Kredit Pemilikan Rumah, Pengusaha Pengadaan Perumahan dan Permukiman. Data yang telah dikumpulkan, baik yang berasal dari data primer maupun sekunder akan dianalisis dengan menggunakan teknik analisis deskriptif kualitatif, yaitu hasil-hasil penelitian disatukan dengan ananlisis data dalam bentuk uraian.

\section{PEMBAHASAN}

A Implikasi Hukum Penggunaan Surat Kuasa Membebankan Hak Tanggungan dalam Perjanjian Kredit Pemilikan Rumah

Rumah menjadi kebutuhan dasar bagi seseorang untuk bertempat tinggal secara layak dalam kehidupan bermasyarakat. ${ }^{9}$ Oleh karena itu pada masa sekarang bisnis perumahan dan permukiman berkembang pesat. Terlebih di Indonesia dengan pertumbuhan penduduk yang relatif cepat. Berbagai upaya menarik perhatian konsumen dilakukan oleh developer salah satunya dengan memberikan fasilitas kredit, yang biasa dinamakan Kredit Pemilikan Rumah (KPR).

KPR memungkinkan seseorang mendapatkan dengan pembayaran secara angsuran, bahkan dapat dilakukan dalam jangka panjang. Pembayaran secara angsuran ini menimbulkan risiko bagi kreditor, karena ada kemungkinan debitor tidak membayar sesuai dengan perjanjian.

Dalam perjanjian jual beli rumah pada umumnya terlebih dahulu diadakan Perjanjanjian Pengikatan Jual Beli (PPJB) antara konsumen dan pengembang. PPJB dilakukan supaya ada ikatan antara pemilik rumah (pengembang) dengan pembeli (konsumen) untuk

melakukan jual beli rumah yang disepakati. PPJB tersebut mencantumkan hal-hal pokok mengenai objek dan subjek perjanjian, hak dan kewajiban para pihak dan sanksi-sanksi jika salah satu pihak wanprestasi. Dengan ditandatanganinya perjanjian pengikatan jual beli rumah antara developer dengan konsumen maka terjadi hubungan hukum antara keduanya.

Perjanjian pengikatan jual beli pada dasarnya bersifat konsensual. Perjanjian tersebut ada atau lahir sejak adanya kata sepakat antara kedua belah pihak yaitu pengembang dan konsumen. Dasar pemikiran hukum mengenai perjanjian pengikatan jual beli adalah bahwa PPJB bukanlah perbuatan hukum jual beli yang bersifat riil dan tunai. Perjanjian pengikatan

\footnotetext{
${ }^{9}$ Supriadi, Hukum Agraria, Jakarta, Sinar grafika, 2012.
} 
jual beli merupakan kesepakatan dua pihak untuk melaksanakan prestasi masing-masing di kemudian hari, yakni pelaksanaan jual beli di hadapan PPAT, bila bangunan telah selesai bersertifikasi dan layak huni.

Menurut Maria S.W. Sumardjono, masalah perjanjian pengikatan jual beli termasuk dalam lingkup hukum perjanjian, sedangkan jual belinya termasuk dalam lingkup hukum tanah nasional yang tunduk pada Undang-undang Pokok Agraria dan peraturan peraturan pelaksanaanya. ${ }^{10}$

Setelah terjadi perjanjian pengikatan jual beli rumah antara developer dengan konsumen, maka timbul kewajiban dan hak masing-masing pihak sebagai subjek hukum, yaitu pihak developer selaku penjual dan pihak konsumen selaku pembeli.

Kewajiban dan hak konsumen adalah:

1) Kewajiban konsumen

a. membaca atau mengikuti petunjuk informasi dan prosedur pemakaian atau pemanfaatan barang dan/atau jasa, demi keamanan dan keselamatan;

b. beritikad baik dalam melakukan transaksi pembelian barang dan/atau jasa;

c. membayar sesuai dengan nilai tukar yang disepakati;

d. mengikuti upaya penyelesaian hukum sengketa perlindungan konsumen.

2) Hak konsumen

Adapun hak calon konsumen dalam perjanjian jual beli rumah adalah sebagai berikut:

a. Berhak memperoleh informasi yang jelas dan terbuka berkaitan dengan pengajuan permohonan membeli rumah secara kredit yang akan dilakukan oleh calon konsumen.

b. Berhak memperoleh perlakuan yang sama seperti calon konsumen yang lainnya.

Developer sebagai pihak yang akan menjual rumah kepada konsumen mempunyai kewajiban dan hak sebagai berikut.

Kewajiban Developer:

1) Memberikan pelayanan atau perlakuan yang sama kepada calon konsumen.

2) Memberikan informasi yang jelas dan terbuka berkaitan dengan pengajuan pembelian rumah oleh calon konsumen.

Hak developer:

1) Meminta calon konsumen memenuhi semua persyaratan yang telah ditetapkan

\footnotetext{
${ }^{10}$ Maria S.W. Sumardjono, Pembangunan Rumah Rusun Dan Permasalahannya:Ditinjau Dari Segi Yuridis Kertas Kerja Untuk Diskusi Terbatas Development of Indonesian Consumer Protection Act (Comparative Studi Dan Draft Evaluation), Jakarta, 1994.
} 
Vol 2, No. (2019): Law, Development \& Justice Review, Mei 2019. e-ISSN: 2655-1942

2) Memberikan penjelasan mengenai syarat-syarat adminsitratif yang harus dipenuhi calon konsumen.

Kredit Pemilihan Rumah (KPR) termasuk dalam kredit konsumtif, karena kredit diberikan kepada debitor untuk membeli rumah sebagai tempat tinggal/dihuni.

Dalam perjanjian Kredit Pemilikan Rumah (KPR) ada 3 (tiga) pihak yang terkait yaitu:

a. Pihak debitor (konsumen) yaitu pihak pembeli rumah yang dibangun oleh developer dengan uang yang dipinjam dari bank.

b. Pihak kreditor yaitu pihak bank sebagai bank penyandang dana yang menberikan bantuan fasilitas kredit dalam bentuk uang yang dipergunakan oleh debitur untuk membayar rumah yang dibeli dari developer.

c. Developer yaitu pengembang dan pembangun proyek-proyek perumahan yaitu rumah-rumah yang dijual kepada pembeli baik secara tunai maupun kredit.

Untuk menjamin pembayaran kredit sesuai dengan ketentuan perjanjian kredit debitor menyetujui memberikan rumah dan tanah yang dibeli dengan kredit bank tersebut sebagai jaminan. Di samping itu, dalam Perjanjian Kredit Pemilikan Rumah pada umumnya disebutkan apabila jaminan berupa rumah dan tanah tersebut dianggap kurang, maka debitor menambah benda-benda tertentu lainnya yang ditetapkan bank untuk dijadikan jaminan tambahan.

Lembaga jaminan yang digunakan adalah Hak Tanggungan. Sebelum berlakunya UU No. 4 Tahun 1996 Tentang Hak Tanggungan (UUHT), hak atas tanah jika dijaminkan menggunakan lembaga hipotik untuk tanah barat dan credietverband untuk tanah adat.

Dari ketentuan Pasal 1 angka 1 UUHT dapat disimpulkan bahwa hak tanggungan terdiri dari beberapa unsur pokok yaitu:

a. Hak tanggungan adalah hak jaminan.

b. Objek hak Tanggungan adalah hak-hak atas tanah sesuai UUPA.

c. Hak Tanggungan dapat dibebankan atas tanahnya saja, tetapi dapat juga dibebankan berikut benda-benda lain yang merupakan satu kesatuan dengan tanah.

d. Utang yang dijamin adalah utang tertentu.

e. Memberikan kedudukan yang diutamakan (preferen) kepada kreditor Penerima Hak Tanggungan Dalam Penjelasan Umum angka 7 UUHT disebutkan bahwa proses pembebanan Hak Tanggungan dilaksanakan melalui dua tahap kegiatan, yaitu: 
Vol 2, No. (2019): Law, Development \& Justice Review, Mei 2019. e-ISSN: 2655-1942

a. tahap pemberian Hak Tanggungan, dengan dibuatnya Akta Pemberian Hak Tanggungan oleh Pejabat Pembuat Akta Tanah, untuk selanjutnyadisebut PPAT, yang didahului dengan perjanjian utang-piutang yang dijamin;

b. tahap pendaftarannya oleh Kantor Pertanahan, yang merupakansaat lahirnya Hak Tanggungan yang dibebankan.

Pasal 10 Ayat (2) UUHT menyebutkan bahwa pemberian Hak Tanggungan dilakukan dengan pembuatan Akta Pemberian Hak Tanggungan oleh PPAT sesuai dengan peraturan perundangundanganyang berlaku.

Pasal 13 UUHT meyebutkan bahwa pemberian Hak Tanggungan wajib didaftarkan pada Kantor Pertanahan. Selambat-lambatnya 7 (tujuh) hari kerja setelah penandatanganan Akta Pemberian Hak, PPAT wajib mengirimkan Akta Pemberian Hak Tanggungan yang bersangkutan dan warkah lain yang diperlukan kepada Kantor Pertanahan. Pendaftaran Hak Tanggungan dilakukan oleh Kantor Pertanahan dengan membuatkan buku-tanah Hak Tanggungan dan mencatatnya dalam buku-tanah hak atas tanah yang menjadi obyek Hak Tanggungan serta menyalin catatan tersebut pada sertifikat hak atas tanah yang bersangkutan. Tanggal buku-tanah Hak Tanggungan adalah tanggal hari ketujuh setelah penerimaan secara lengkap surat-surat yang diperlukan bagi pendaftarannya dan jika hari ketujuh itu jatuhpada hari libur, buku-tanah yang bersangkutan diberi bertanggal hari kerjaberikutnya. Hak Tanggungan lahir pada hari tanggal buku-tanah HakTanggungan.

Pada asasnya pembebanan Hak Tanggungan wajib dilakukan sendiri oleh pemberi Hak Tanggungan. Hanya apabila benar-benar diperlukan, yaitu dalam hal pemberi Hak Tanggungan tidak dapat hadir di hadapan PPAT, diperkenankan penggunaan Surat Kuasa Membebankan Hak Tanggungan. Sejalan dengan itu, surat kuasa tersebut harus diberikan langsung oleh pemberi Hak Tanggungan dan harus memenuhi persyaratan mengenai muatannya. Tidak dipenuhinya syarat ini mengakibatkan surat kuasa yang bersangkutan batal demi hukum, yang berarti bahwa surat kuasa yang bersangkutan tidak dapat digunakan sebagai dasar pembuatan Akta Pemberian Hak Tanggungan. PPAT wajib menolak permohonan untuk membuat Akta Pemberian Hak Tanggungan, apabila Surat Kuasa Membebankan Hak Tanggungan tidak dibuat sendiri oleh pemberi Hak Tanggungan atau tidak memenuhi persyaratan. 
Vol 2, No. (2019): Law, Development \& Justice Review, Mei 2019. e-ISSN: 2655-1942

Pasal 15 Ayat (1) UUHT menyebutkan bahwa Surat Kuasa Membebankan Hak Tanggungan wajib dibuat dengan akta notaris atau akta PPAT dan memenuhi persyaratan sebagai berikut:

a. tidak memuat kuasa untuk melakukan perbuatan hukum lain daripada membebankan Hak Tanggungan;

b. tidak memuat kuasa substitusi;

c. mencantumkan secara jelas obyek Hak Tanggungan, jumlah utangdan nama serta identitas kreditornya, nama dan identitas debitor apabiladebitor bukan pemberi Hak Tanggungan.

Pasal 15 Ayat (2) UUHT menentukan bahwa Kuasa Untuk Membebankan Hak Tanggungan tidak dapat ditarik kembali atau tidak dapat berakhir oleh sebab apapun juga kecuali karena kuasa tersebut telah dilaksanakan atau karena telah habis jangka waktunya.

Mengenai jangka waktu Surat Kuasa Membebankan Hak Tanggungan diatur dalam diatur dalam Pasal 15 Ayat (3) dan (4). Surat Kuasa Membebankan Hak Tanggungan mengenai hak atas tanah yang sudah terdaftar wajib diikuti dengan pembuatan Akta Pemberian Hak Tanggungan selambat-lambatnya 1 (satu) bulan sesudah diberikan. Surat Kuasa Membebankan Hak Tanggungan mengenai hak atastanah yang belum terdaftar wajib diikuti dengan pembuatan Akta Pemberian HakTanggungan selambat-lambatnya 3 (tiga) bulan sesudah diberikan.

Pasal 15 Ayat (5) menyebutkan bahwa ketentuan sebagaimana dimaksud pada ayat (3) dan ayat (4) tidak ber-laku dalam hal Surat Kuasa Membebankan Hak Tanggungan diberikan untuk menjamin kredit tertentu yang ditetapkan dalam peraturan perundang-undangan yang berlaku.

Selanjutnya Pasal 15 Ayat (6) menyebutkan bahwa Surat Kuasa Membebankan Hak Tanggungan yang tidak diikutidengan pembuatan Akta Pemberian Hak Tanggungan dalam waktu yang ditentukansebagaimana yang dimaksud pada ayat (3) atau ayat (4), atau waktu yangditentukan menurut ketentuan sebagaimana yang dimaksud pada ayat (5) batal demihukum.

Penjelasan Pasal 15 ayat (5) UUHT menentukan bahwa ketentuan Pasal 15 ayat (3) dan (4) tersebut tidak berlaku bagi SKMHT untuk jenis kredit tertentu, yaitu KUK, KUT, KPR. Menurut Pasal 1 Peraturan Menteri Agraria No. 4 tahun 1994 tentang Penetapan Batas Waktu penggunaan SKMHT untuk menjamin pelunasan kredit tertentu, jangka waktu berlakunya SKMHT " sampai saat berakhirnya perjanjian pokok yang bersangkutan. " 
Vol 2, No. (2019): Law, Development \& Justice Review, Mei 2019. e-ISSN: 2655-1942

Kredit Pemilikan Rumah (KPR) yang diberikan untuk pengadaan perumahan menurut Pasal 1 angka 2 Peraturan Menteri Negara Agraria/Kepala BPN No. 4 Tahun 1994 tentang Penetapan Batas Waktu Penggunaan Surat Kuasa Membebankan Hak Tanggungan (SKMHT) untuk menjamin Jenis-jenis Kredit Tertentu yaitu:

a. Kredit yang diberikan untuk membiayai pemilikan rumah ini, Rumah Sederhana atau Rumah Susun dengan luas tanah $200 \mathrm{~m}$ (dua ratus meter persegi) dan luas bangunan tidak lebih dari 70 $\mathrm{m}$ (tujuh puluh meter persegi).

b. Kredit yang diberikan untuk pemilikan kapling siap bangun (KSB) dengan luas tanah $54 \mathrm{~m}$ (lima puluh empat meter persegi) sampai dengan $72 \mathrm{~m}$ (tujuh puluh dua meterpersegi) dan kredit yang diberikan untuk membiayai bangunannya.

c. Kredit yang diberikan untuk perbaikan/pemugaran rumah sebagaimana dimaksud huruf a dan b. Apabila proses Hak Tanggungan baru sampai pada pembuatan SKMHT, maka Hak Tanggungan belum lahir atau belum terjadi. Hal tersebut dikatakan secara tegas pada Pasal 13 UUHT bahwa lahirnya adalah pada saat pendaftaran Hak Tanggungan di Kantor Pertanahan. Dalam hal SKMHT belum dilanjutkan dengan pembuatan Akta Pemberian Hak Tanggungan dan pendaftaran Hak Tanggungan maka Hak Tanggungan yang bersangkutan belum terjadi. Dengan demikian Kreditor tidak memperoleh hak-hak sebagai kreditor preferen sebagaiamana diatur dalam UUHT.

\section{B. Akibat Hukum Debitor Wanprestasi dalam Pembebanan Hak Tanggungan dengan menggunakan SKMHT}

Dalam perjanjian ada kemungkinan salah satu pihak tidak memenuhi prestasi yang dikatakan sebagai wanprestasi. Bentuk wanprestasi dapat berupa:
a. Tidak melakukan apa yang disanggupi akan dilakukannya;
b. Melaksanakan apa yang dijanjikan, tetapi tidak sebagaimana diperjanjikannya;
c. Melakukan apa yang diperjanjikan namun terlambat;
d. Melakukan sesuatu menurut perjanjian tidak boleh dilakukannya. ${ }^{11}$

Dalam hal debitor wanprestasi maka berdasarkan Pasal 1276 KUHPerdata kreditor dapat menggugat hal-hal sebagai berikut:

1. Memenuhi/melaksanakan perjanjian;

2. Memenuhi perjanjian disertai keharusan membayar ganti rugi;

3. Membayar ganti rugi;

4. Membatalkan perjanjian; dan

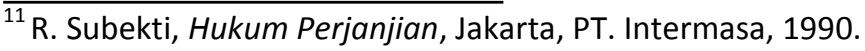


Vol 2, No. (2019): Law, Development \& Justice Review, Mei 2019. e-ISSN: 2655-1942

5. Membatalkan perjanjian disertai dengan ganti rugi

Jika debitor wanprestasi dan kreditor memiliki hak jaminan kebendaan salah satunya Hak Tanggungan maka kreditor dapat melakukan haknya berdasarkan Pasal 20 UUHT yaitu:

1. Berdasarkan hak pemegang Hak Tanggungan pertama untuk menjual objek Hak Tanggungan sebagaimana dimaksud dalam Pasal 6, atau

2. Berdasarkan titel eksekutorial yang terdapat dalam sertipikat HakTanggungan sebagaimana dimaksud dalam Pasal 14 ayat (2), objek Hak Tanggungan dijual melalui pelelangan umum menurut tata cara yang ditentukan dalamperaturan perundang-undangan untuk pelunasan piutang pemegang Hak Tanggungandengan hak mendahulu dari pada kreditor-kreditorlainnya.

3. Atas kesepakatan pemberi dan pemegang Hak Tanggungan, penjualan obyek Hak Tanggungan dapat dilaksanakan di bawah tangan jika dengandemikian itu akan dapat diperoleh harga tertinggi yang meng-untungkan semuapihak.

Kuasa untuk membebankan Hak Tanggungan tidak dapat berakhir oleh sebab apapun, kecuali karena kuasa tersebut telah dilaksanakan atau karena telah habis jangka waktunya. Ketentuan ini dimaksud agar supaya pemberian Hak Tanggungan benar-benar dilaksanakan sehingga memberikan kepastian hukum baik bagi pemegang maupun pemberi Hak Tanggungan. Dalam Pasal 15 ayat (1c) UUHT, harus dicantumkan secara jelas dalam SKMHT yaitu objek Hak Tanggungan sebagai bentuk perlindungan dan demi kepastian hukum baik untuk penerima maupun pemberi kuasa, mengingat bahwa kuasa tersebut hanya dibuat dalam keadaan yang sangat khusus, dan dengan persyaratan yang ketat, serta jangka waktu berlakunya dibatasi.

Dalam perjanjian KPR seringkali pemberian Hak Tanggungan hanya dengan membuat SKMHT, dengan alasan hak atas tanah yang dijaminkan, kepemilikannya belum atas nama pemberi Hak Tanggungan, karena sertifikat hak atas tanah belum dilakukan pemecahan secara individual (digabung). Jangka waktu berlakunya SKMHT yang digunakan untuk menjamin perjanjian KPR menurut Peraturan Menteri Agraria/Kepala BPN No. 4 Tahun 1996 berlaku sampai saat berakhirnya masa berlakunya perjanjian pokok. Jadi sepanjang perjanjian KPR berlangsung, SKMHT tersebut masih berlaku, tanpa dibuat Akta Pemberian Hak Tanggungan (APHT).

Tujuan pemberian kuasa untuk membebankan Hak Tanggungan (SKMHT) adalah mengingat langkah pemasangan jaminan dengan Hak Tanggungan tidak mudah, harus harus melalui formalitas tertentu, memakan waktu lama dan biaya yang tidak sedikit, dan hak atas 
tanah belum menjadi hak milik dari pemberi jaminan maka adakalanya untuk kredit yang diberikan kreditor merasa sudah cukup terjamin apabila telah mendapat kuasa dari debitur untuk memasang jaminan.

Apabila debitor wanprestasi, sementara Hak Tanggungan hanya dilakukan dengan Surat Kuasa Membebabnkan Hak Tanggungan, maka Hak Tanggungan belum terjadi. Oleh karena itu kreditor tidak memiliki hak sebagai Penerima Hak Tanggungan, dengan demikian tidak dapat melakukan eksekusi seperti halnya cara eksekusi objek Hak Tanggungan yang diatur dalam Pasal 20 UUHT. Kreditor juga tidak berkedudukan sebagai kreditor Preferen. Dalam hal ini kreditor hanya dapat melakukan gugatan ke pengadilan jika debitor wanprestasi, karena tidak ada jaminan khusus yang berupa jaminan kebendaan. Dalam hal ini hanya ada jaminan umum sebagaimana ditentukan dalam Pasal 1131 KUH Perdata bahwa seluruh harta benda milik debitor menjadi jaminan bagi perikatan debitor tersebut kepada para kreditor. Pasal 1132 KUH Perdata menyebutkan bahwa seluruh harta benda milik debitor tersebut menjadi jaminan bersama bagi para kreditor dan pembagiannya seimbang menurut besar kecilnya piutang mereka masing-masing terkecuali ada alasanalasn yang sah untuk mendahulukan piutang yang satu terhadap piutang yang lain.

\section{SIMPULAN DAN SARAN}

\section{Simpulan}

1. Penggunaan Surat Kuasa Membebankan Hak Tanggungan sebagai jaminan dalam Kredit Pemilikan Rumah seringkali dilakukan oleh para pihak sampai masa kredit berakhir. Hal ini berakibat belum terjadi Hak Tanggungan, sehingga kreditor tidak memiliki jaminan khusus berupa jaminan kebendaan.

2. Apabila dalam masa pembebanan Hak Tanggungan dilaksanakan dengan menggunakan SKMHT ternyata debitor wanprestasi, maka kreditor tidak memiliki hak sebagai pemegang jaminan kebendaan. Dalam hal ini kreditor tidak dapat melakukan eksekusi objek jaminan karena belum terjadi Hak Tanggungan. Kreditor tidak berkedudukan sebagai kreditor preferen. Dalam hal debitor wanprestasi hanya dapat melakukan gugatan ke pengadilan sebagai upaya terakhir.

\section{Saran}

Kreditor dalam penggunaan Surat Kuasa Membebbankan Hak Tanggungan sebaiknya segera melanjutkan dengan pembuatan Akta Pemberian Hak Tanggungan dan 
Vol 2, No. (2019): Law, Development \& Justice Review, Mei 2019. e-ISSN: 2655-1942

mendaftarkannya di Kantor Pertanahan supaya terjadi Hak Tanggungan. Dengan demikian akan memperoleh perlindungan hukum sebagai pemegang jaminan kebendaan.

\section{DAFTAR PUSTAKA}

\section{Buku dan Jurnal}

Badriyah, Siti Malikhatun, 2010, Penemuan Hukum Dalam Konteks Pencarian Keadilan.

Semarang: Badan Penerbit Universitas Diponegoro. 2016, Problematika Pembebanan Hak Tanggungan, Masalah - Masalah Hukum 45, No. 3.

Cahyadi, Made Oka, Surat Kuasa Membebankan Hak Tanggungan Dan Pengaruhnya Terhadap Pemenuhan Asas Publisitas Dalam Proses Pemberian Hak Tanggungan, Jurnal Legislasi Indonesia 14, No. 4 2017): 439-46.

Doly, Denico. "Aspek Hukum Hak Tanggungan Dalam Pelaksanaan Roya." Negara Hukum, Membangun Hukum Untuk Keadilan Dan Kesejahteraan 2, no. 1 (2011): 103-28.

Maulana, Ayang Fristia. "Surat Kuasa Membebankan Hak Tanggungan Atas Tanah Negara." Jurnal Yuridis 4, no. 2 (2017): 192-204. doi:P-ISSN: 1693-4458 E-ISSN: 2598-5906.

Nurjannah, St. "Eksistensi Hak Tanggungan Sebagai Lembaga Jaminan Hak Atas Tanah

(Tinjauan Filosofis)." Jurisprudentie : Jurusan IImu Hukum Fakultas Syariah Dan Hukum

5, no. 1 (2019): 195. doi:10.24252/jurisprudentie.v5i2.5439.

R. Subekti. Hukum Perjanjian. XII. Jakarta: PT. Intermasa, 1990.

Sudikno Mertokusumo dan Mr. A. Pitlo. Bab-Bab Tentang Penemuan Hukum (Chapters on Rechsvinding). 2nd ed. Jakarta: . in collaboration with the Ministry of Education and Culture Law Consortium and The Asia Foundation, 2013.

Sumardjono, Maria S.W. “Pembangunan Rumah Rusun Dan Permasalahannya:Ditinjau Dari Segi Yuridis Kertas Kerja Untuk Diskusi Terbatas Development of Indonesian Consumer Protection Act (Comparative Studi Dan Draft Evaluation)." Jakarta, 1994.

Supriadi. Hukum Agraria. Jakarta: sinar grafika, 2012.

Suwandi, Dimas Nur Arif Putra. "Perlindungan Hukum Bagi Bank Pemegang Hak Tanggungan Peringkat Kedua Dalam Eksekusi Objek Hak Tanggungan." Media Iuris 1, no. 3 (2019): 420. doi:10.20473/mi.v1i3.10183. 
Vol 2, No. (2019): Law, Development \& Justice Review, Mei 2019. e-ISSN: 2655-1942 